\title{
What to do and what not to do in serological diagnosis of pertussis: recommendations from $\mathrm{EU}$ reference laboratories
}

\author{
N. Guiso • G. Berbers • N. K. Fry • Q. He • \\ M. Riffelmann • C. H. Wirsing von König • \\ EU Pertstrain group
}

Received: 26 August 2010 /Accepted: 18 October 2010 /Published online: 11 November 2010

(C) The Author(s) 2010. This article is published with open access at Springerlink.com

\begin{abstract}
Bordetella pertussis-specific antibodies can be detected by enzyme-linked immunosorbent assays (ELISAs) or multiplex immunoassays. Assays use purified or mixed antigens, and only pertussis toxin (PT) is specific for $B$. pertussis. The interpretation of results can be based on dual-sample or single-sample serology using one or two cut-offs. The EU Pertstrain group recommends that: (i) ELISAs and multiplex immunoassays should use purified non-detoxified PT as an antigen, that they should have a broad linear range and that they should express results quantitatively in International Units per millilitre (IU/ml); (ii) a single or dual diagnostic cut-off for singleserum serology using IgG-anti-PT between 50 and $120 \mathrm{IU} / \mathrm{ml}$ should be used, and diagnostic serology cannot be validly interpreted for one year after vaccination with acellular pertussis (aP) vaccines; (iii) IgA-anti-PT should only be used
\end{abstract}

Members of the EU Pertstrain group are listed in the appendix.

\section{N. Guiso}

Institut Pasteur,

Paris, France

\section{G. Berbers}

National Institute for Public Health and the Environment,

Bilthoven, The Netherlands

N. K. Fry

Health Protection Agency Centre for Infections,

London, UK

Q. He

National Institute for Health and Welfare,

Turku, Finland

M. Riffelmann • C. H. Wirsing von König $(\bowtie)$

Institut für Hygiene und Labormedizin, HELIOS Klinikum

Krefeld,

Lutherplatz 40,

47805, Krefeld, Germany

e-mail: carlheinz.wirsingvonkoenig@helios-kliniken.de with indeterminate IgG-anti-PT levels or when a second sample cannot be obtained. This group discourages using: (i) other antigens in routine diagnostics, as they are not specific; (ii) micro-agglutination, due to its lack of sensitivity; (iii) immunoblots for pertussis serodiagnosis, as results cannot be quantified; (iv) other methods, such as complement fixation or indirect immunofluorescence, due to their low sensitivity and/ or specificity.

\section{Indications for pertussis diagnostics}

The diagnosis of pertussis should only be attempted in patients with symptoms compatible with pertussis, such as prolonged coughing with paroxysms and/or whooping or choking. In infants, older vaccinated children, adolescents and adults, the clinical course may not be typical, and prolonged coughing may be the only symptom. In these cases, the diagnosis of pertussis requires laboratory methods for confirmation.

Direct and indirect tests are available. Direct tests are real-time polymerase chain reaction (PCR) and culture, whereas indirect tests measure specific antibodies in oral fluid or sera. Here, we focus on the detection of antibodies against Bordetella pertussis antigens.

\section{Development of the recommendations}

The EU Pertstrain group consists of representatives of the Bordetella reference laboratories in their respective EU countries. In a face-to-face meeting at the Istituto Superiore di Sanità (ISS), Rome, Italy, in 2009, the outline of a manuscript was discussed and agreed upon. After a search of relevant databases, a first draft was written (NG) and intensively reviewed by members of the group. In a second face-to-face meeting, at the Rijksinstituut voor 
Volksgezondheid en Milieu (RIVM), Bilthoven, the Netherlands, in June 2010, the draft recommendations were broadly discussed and agreed upon. A second version of the recommendations was drafted ( $\mathrm{NG}, \mathrm{CHWvK})$. This version was then reviewed again by all authors.

\section{Serological tests}

\section{Blood/serum}

Most serological assays are validated to test serum; some may also be validated to test heparinised plasma or ethylenediaminetetraacetic acid (EDTA) plasma. Capillary blood samples may be used if a sufficient volume cannot be obtained otherwise. Serum or plasma must be separated as soon as possible after blood sampling ( $24 \mathrm{~h}$ at room temperature). If acute and convalescent serum samples taken at least three weeks apart from one individual are available, they should be tested together in one run. All serum samples may be frozen $\left(\right.$ at $-20^{\circ} \mathrm{C}$ ) after the primary assay and re-analysed later together with a possible second sample.

\section{ELISA in serum samples}

In preparation for the acellular vaccine studies in the 1990s, the enzyme-linked immunosorbent assay (ELISA) methodology, the type of antigens, as well as the reference sera have been standardised, and they have been used in all acellular vaccine trials, in sero-epidemiological studies in many countries and for diagnostic purposes in various laboratories [1-5].

\section{Antigens}

ELISA is normally done with highly purified antigens. The antigens most frequently used are pertussis toxin (PT) and filamentous haemagglutinin (FHA), and to a lesser extent, pertactin (PRN) and fimbriae (FIM). Sometimes, adenylate cyclase-haemolysin toxin (ACT) is also used. These antigens are used in their active, i.e. non-detoxified, form. The storage conditions of the antigens as well as the duration of storage can vary significantly according to the manufacturers who provide the purified antigens. Anti-PT antibodies are specific for B. pertussis, whereas anti-FHA, anti-PRN, anti-FIM and anti-ACT are less specific due to cross-reactivity with other microbial antigens (e.g. other Bordetella species, Haemophilus species, Mycoplasma pneumoniae, Escherichia coli). For this reason, in routine diagnosis, only the measurement of anti-PT antibodies is recommended. However, the measurement of other antibodies may be used for transmission, immunogenicity or vaccine non-inferiority studies. Some ELISAs, especially commercial kits, use a mixture of antigens or supernatants or sonicates of whole $B$. pertussis cells. The use of kits with mixed antigens is not recommended [6].

\section{Reference sera}

World Health Organization (WHO) references are available from the National Institute for Biological Standards and Control (NIBSC, Potters Bar, UK) ("WHO International Standard (06/140)" and "WHO Reference Reagent (06/ 142 )") for the measurement of human antibodies to $B$. pertussis antigens, and, thus, quantitative results should be reported in IU/ml [7].

\section{Plates}

For in-house ELISAs, differences between plates were observed, and Thermo Scientific Nunc MaxiSorp (Nunc AS, Copenhagen, Denmark) plates and Greiner MICROLON High Binding (Greiner Bio-One, Frickenhausen, Germany) plates seemed to work better than others [8].

\section{Flow cytometry}

Bead-based multiplex assays that simultaneously measure antibodies to various antigens have also been applied to $B$. pertussis antigens. The assays use fluorescent microparticles to which purified antigens are covalently coupled and are based on a proprietary method patented in 1983 in Germany [9] or on xMAP Technology from Luminex ${ }^{\mathrm{TM}}$ [10]. These assays seem to produce results comparable to conventional ELISA systems.

\section{Immunoblots, line and dot blots}

Many commercial kits detect anti-B. pertussis and/or anti-PT, anti-FHA, anti-PRN and also ACT antibodies in serums using blotting techniques. Kits using whole-cell suspensions as antigens are not specific for the detection/diagnosis of pertussis infections due to the great cross-reactivity with other bacteria (e.g. other Bordetella species, Haemophilus species, Mycoplasma pneumoniae). Antigens used in these kits have to be validated concerning their purity, as contamination with other antigens or antigen aggregates can also produce false-positive results. A quantitative interpretation of blot results is not possible, but a semi-quantitative reporting may be possible. Although various CE-marked commercial kits are available, a recent comparison showed significant differences between kits and an insufficient correlation to the values of the 1st International Reference Preparation (Kennerkuecht et al. submitted). Consequently, the use of immunoblots for pertussis serology is not recommended by the EU Pertstrain group. 


\section{Micro-agglutination}

Micro-agglutination has been widely used before ELISA systems became available [11]. As with other bacterial agglutination assays, micro-agglutination with $B$. pertussis cells mainly measures IgM antibodies to outer surface antigens such as FIM, PRN and lipooligosaccharide (LOS). Results are reported in titres starting at 1:20 or 1:40. No agglutinin titre has been attributed to the WHO reference preparation so far. Agglutinating antibodies can be used to measure the exposure of a population to $B$. pertussis antigens; on an individual level, the micro-agglutination method is not useful for confirming the clinical diagnosis of pertussis.

\section{CHO cell neutralisation}

This test used the ability of PT to induce characteristic morphological changes in a culture of Chinese hamster ovary (CHO) cells. These changes can be neutralised by the presence of anti-PT antibodies. The titres of $\mathrm{CHO}$ cell-neutralising antibodies correlate well with the IgG-anti-PT ELISA values, and, thus, $\mathrm{CHO}$ cell assays are rarely used for diagnostic purposes $[8,12]$. The interpretation of $\mathrm{CHO}$ assays cannot be standardised, and it is difficult to interpret the morphological changes and to score the results objectively.

\section{Complement fixation}

Complement fixation using whole cells of $B$. pertussis has been rarely used and suffers from a lack of sensitivity and specificity.

\section{Indirect immunofluorescence}

Indirect immunofluorescence using whole cells of $B$. pertussis has the same disadvantages as complement fixation

\section{Oral fluid}

Oral fluid can be sampled by standardised means, e.g. Oracol swabs (Malvern Medical Developments) or OraSure oral specimen collection devices (OraSure Technologies Inc.). The diagnostic sensitivity of measuring antibodies in oral fluid samples is lower $(\sim 80 \%)$ as compared to serum samples, but the samples can easily be obtained and offer an adjunct to diagnostic serology

\section{ELISA in oral fluid}

An IgG-capture ELISA capable of detecting anti-PT IgG in oral fluid has been developed. The assay was evaluated by comparison to a serum ELISA. The results showed that the oral fluid assay detected seropositive subjects with a sensitivity of $79.7 \%$ [95\% confidence interval (CI) $68.3-88.4]$ and a specificity of $96.6 \%$ (95\% CI 91.5-99.1) relative to the ELISA [13]. This assay has since been modified to include a monoclonal capture antibody; however, no commercial assays for measuring antibodies in oral fluid are available.

\section{Reporting of serological results using ELISA or flow cytometry}

Concentrations of antibodies to $B$. pertussis antigens should be quantitatively expressed in IU $/ \mathrm{ml}$ as reference preparations are available [7]. The reference preparation defines values for antibodies of isotypes $\operatorname{IgG}$ and $\operatorname{IgA}$ to PT, FHA, PRN and to FIM. Assigned values of the reference preparation are described in Table 1. The numerical values of IU $/ \mathrm{ml}$ are equivalent to the previously used ELISA units $/ \mathrm{ml}(\mathrm{EU} / \mathrm{ml})$ derived from the human reference preparations lot 3 , lot 4 and lot 5 from the Center for Biologics Evaluation and Research/Food and Drug Administration (CBER/FDA), Bethesda, MD, USA.

\section{Interpretation of serological results}

PT and FHA are contained in substantial amounts in all acellular vaccines licensed in Europe (except in Denmark), and PRN and FIM are also components of licensed acellular pertussis vaccines. Thus, the immune response against infection or vaccination cannot be distinguished and pertussis vaccination may interfere with the interpretation of serological results. Due to a continuous circulation of Bordetellae in the population, IgG-anti-PT and other antibodies to Bordetella antigens are detectable in the majority of all adolescent and adult populations tested so far [14]. Thus, serological diagnosis of pertussis must be performed in immunological non-naïve populations with different kinetics of antibody production.

Additionally, pertussis serology suffers from various other drawbacks:

- Commercial ELISAs are of different antigen composition and quality

- Reference antigens with good purity are not easily available

- Population-based cut-offs for single-sample serology may need verification after changes in the vaccination schedule

- Interpretation of anti-PT concentrations in recently vaccinated persons is difficult

Dual-sample serology based on $\geq 100 \%$ increase in antibody concentration or on $\geq 50 \%$ decrease in antibody concentration is a sensitive and specific method for serological diagnosis $[1,4]$. However, even in paired sera, no antibody increase may be seen after infection due to the secondary immune response, and the diagnosis may also be 
Table 1 Reference preparations from the World Health Organization (WHO) and the Center for Biologics Evaluation and Research/Food and Drug Administration (CBER/FDA). Values are given in $\mathrm{IU} / \mathrm{ml}$ for the WHO preparations and in ELISA units $(\mathrm{EU}) / \mathrm{ml}$ for the CBER/ FDA preparations; IU $/ \mathrm{ml}$ and EU/ml are numerically identical [7]

\begin{tabular}{lllllll}
\hline & IgG-anti-PT & IgA-anti-PT & IgG-anti-FHA & IgA-anti-FHA & IgG-anti-PRN & IgA-anti-PRN \\
\hline WHO international standard (06/140) & $335 \mathrm{IU} / \mathrm{ml}$ & $65 \mathrm{IU} / \mathrm{ml}$ & $130 \mathrm{IU} / \mathrm{ml}$ & $65 \mathrm{IU} / \mathrm{ml}$ & $65 \mathrm{IU} / \mathrm{ml}$ & $42 \mathrm{IU} / \mathrm{ml}$ \\
WHO reference reagent (06/142) & $106 \mathrm{IU} / \mathrm{ml}$ & $18 \mathrm{IU} / \mathrm{ml}$ & $122 \mathrm{IU} / \mathrm{ml}$ & $86 \mathrm{IU} / \mathrm{ml}$ & $39 \mathrm{IU} / \mathrm{ml}$ & $38 \mathrm{IU} / \mathrm{ml}$ \\
CBER/FDA \#3 & $200 \mathrm{EU} / \mathrm{ml}$ & $15 \mathrm{EU} / \mathrm{ml}$ & $200 \mathrm{EU} / \mathrm{ml}$ & $100 \mathrm{EU} / \mathrm{ml}$ & $\mathrm{ND}$ & $\mathrm{ND}$ \\
CBER/FDA \#5 & $\mathrm{ND}$ & $140 \mathrm{EU} / \mathrm{ml}$ & $\mathrm{ND}$ & $280 \mathrm{EU} / \mathrm{ml}$ & $\mathrm{ND}$ & $90 \mathrm{EU} / \mathrm{ml}$ \\
CBER/FDA \#4 & $\mathrm{ND}$ & $\mathrm{ND}$ & $\mathrm{ND}$ & $\mathrm{ND}$ & $90 \mathrm{EU} / \mathrm{ml}$ & $25 \mathrm{EU} / \mathrm{ml}$ \\
\hline
\end{tabular}

ND, not declared

based on a decrease of antibodies, which may be too slow to reach $50 \%$ between the acute and convalescent sample.

In clinical practice, diagnosis is mostly based on singlesample serology using a single or a more continuous cutoff. For single-sample serology, various cut-off values for IgG-anti-PT have been proposed (Table 2). In Massachusetts, $100 \mathrm{EU} / \mathrm{ml}$ was used, and, later, in order to increase specificity, > 200 EU/ml IgG-anti-PT $(>20 \mu \mathrm{g} / \mathrm{ml})$ was employed. In the Netherlands, a cut-off $>\sim 125 \mathrm{EU} / \mathrm{ml}$ IgGanti-PT with higher specificity or $62 \mathrm{EU} / \mathrm{ml}$ with slightly lower specificity has been used $[15,16]$. In Germany, a cutoff of $\sim 40 \mathrm{EU} / \mathrm{ml}$ IgG-anti-PT was suggested, together with $\sim 50 \mathrm{EU} / \mathrm{ml}$ IgA-anti-FHA. A sero-epidemiological survey was recently performed in various countries in Western Europe using a cut-off of $125 \mathrm{EU} / \mathrm{ml}$ for recent infection, and it can be used as a population-based reference [14]. Another recently completed sero-surveillance in US sera found that three populations could be separated according to their levels of IgG-anti-PT: one cut-off was estimated at $94 \mathrm{EU} / \mathrm{ml}$ and a lower cut-off was estimated at $48 \mathrm{EU} / \mathrm{ml}$ [17]. Using the lower $50 \mathrm{EU} / \mathrm{ml}$ cut-off may be especially useful in outbreak situations, and, overall, this cut-off of 50 $\mathrm{EU} / \mathrm{ml}$ seems to be more appropriate for diagnosis rather than a higher cut-off with lower sensitivity [18].

Overall, it is astonishing that, irrespective of various vaccination strategies, cut-offs for single-sample serology are comparable throughout the countries in which they were evaluated.

Table 2 Suggested cut-off values for IgG-anti-PT for adolescents and adults. Adapted from WHO "The Immunological Basis for Immunization Series" (available online at: http:// whqlibdoc.who.int/publications/ 2010/9789241599337_eng.pdf)

MA, Massachusetts
n.a., not applicable

A comparison of receiver operating characteristic (ROC) curve analyses with data from Denmark, the Netherlands and the UK showed that, for all three countries, the single cut-off with optimal sensitivity and specificity may be in the range between 60 and $75 \mathrm{IU} / \mathrm{ml}$.

It may be sensible to use a dual cut-off between 62 and $125 \mathrm{IU} / \mathrm{ml}$ according to countries as a proof of a recent infection with $B$. pertussis, provided that the patient was not vaccinated during the last 12 months (Table 2). If diagnosis cannot be established with certainty from a single serum, but is deemed to be necessary according to the clinical symptoms, antibodies should be measured in a second (convalescent) serum sample at two to four weeks interval. In case of nonavailability of a second serum sample, measurement of $\operatorname{IgA}$ anti-PT antibodies can be an alternative, but no broadly accepted cut-off is available for this antibody subclass. Considering its relatively high specificity and low sensitivity, a cut-off near the minimal level of quantification, which may be between 10 and $20 \mathrm{IU} / \mathrm{ml}$, may seem reasonable [19].

\section{Recommendations for serological testing with suspected pertussis}

In neonates and young infants, PCR and/or culture should be performed on nasopharyngeal samples, nasopharyngeal swabs (NPSs) or nasopharyngeal aspirates (NPAs) as soon as possible post-onset of symptoms. The measurement of

\begin{tabular}{llllll}
\hline Country & Type of study & Cut-off & Sensitivity & Specificity & Reference \\
\hline MA, USA & Population study & $\sim 100 \mathrm{IU} / \mathrm{ml}$ & $78 \%$ & $98 \%$ & {$[20]$} \\
MA, USA & Population study & $\sim 200 \mathrm{IU} / \mathrm{ml}$ & $67 \%$ & $99.9 \%$ & {$[21]$} \\
NL & Population study & $125 \mathrm{IU} / \mathrm{ml}$ & $70 \%$ & $99 \%$ & {$[15]$} \\
& & $62 \mathrm{IU} / \mathrm{ml}$ & $80 \%$ & $95 \%$ & \\
D & Population study & $40 \mathrm{IU} / \mathrm{ml}$ & $80 \%$ & $95 \%$ & {$[22]$} \\
EU & Epidemiological survey & $125 \mathrm{IU} / \mathrm{ml}$ & n.a. & n.a. & {$[14]$} \\
USA & Epidemiological survey, model & $94 \mathrm{IU} / \mathrm{ml}$ & n.a. & n.a. & {$[17]$} \\
& & $46 \mathrm{IU} / \mathrm{ml}$ & n.a. & & \\
AUS & Clinical validation & $50 \mathrm{IU} / \mathrm{ml}$ & Better than & $100 \mathrm{IU} / \mathrm{ml}$ & {$[18]$} \\
\hline
\end{tabular}


IgG-anti-PT is only meaningful for older children/adults, including parents and other household members. In vaccinated children, adolescents and adults with less than two weeks of coughing culture and PCR from nasopharyngeal samples should be done. For adolescents and adults with coughing of less than three weeks, PCR and the measurement of IgG-anti-PT should be performed [1]. If coughing lasted at least 2 to 3 weeks, the measurement of IgG-anti-PT should be sufficient. In outbreak situations,
PCR and culture should be performed from nasopharyngeal samples and IgG-anti-PT should be measured in serum samples.

Open Access This article is distributed under the terms of the Creative Commons Attribution Noncommercial License which permits any noncommercial use, distribution, and reproduction in any medium, provided the original author(s) and source are credited.

\section{Appendix}

Table 3 shows the members of the EU Pertstrain group.

Table 3 List of participants of the EU Pertstrain network

\begin{tabular}{|c|c|c|c|}
\hline Members & Email address & Name of organisation & Town, country \\
\hline $\begin{array}{l}\text { Qiushui He } \\
\text { and Jussi } \\
\text { Mertsola }\end{array}$ & qiushui.he@utu.fi; Jussi.Mertsola@utu.fi & $\begin{array}{l}\text { National Institute for } \\
\text { Health and Welfare, } \\
\text { University of Turku }\end{array}$ & Turku, Finland \\
\hline $\begin{array}{l}\text { Carl Heinz } \\
\text { Wirsing von } \\
\text { König and } \\
\text { Marion } \\
\text { Riffelmann }\end{array}$ & $\begin{array}{l}\text { carlheinz.wirsingvonkoenig@helios-kliniken.de; marion. } \\
\text { riffelmann@helios-kliniken.de }\end{array}$ & $\begin{array}{l}\text { HELIOS Klinikum } \\
\text { Krefeld }\end{array}$ & Krefeld, Germany \\
\hline $\begin{array}{l}\text { Nicole Guiso and } \\
\text { Sophie Guillot }\end{array}$ & nicole.guiso@pasteur.fr; sophie.guillot@pasteur.fr & Institut Pasteur & Paris, France \\
\hline $\begin{array}{l}\text { Hans Hallander } \\
\text { and Abdolreza } \\
\text { Advani }\end{array}$ & hans.hallander@smi.se; reza.advani@smi.se & $\begin{array}{l}\text { Swedish Institute for } \\
\text { Infectious Disease } \\
\text { Control }\end{array}$ & Solna, Sweden \\
\hline $\begin{array}{l}\text { Frits R Mooi and } \\
\text { Guy Berbers }\end{array}$ & frits.mooi@rivm.nl; guy.berbers@rivm.nl & $\begin{array}{l}\text { National Institute of } \\
\text { Public Health and } \\
\text { the Environment }\end{array}$ & $\begin{array}{l}\text { Bilthoven, the } \\
\text { Netherlands }\end{array}$ \\
\hline Anna Lutyńska & agzyl@pzh.gov.pl & $\begin{array}{l}\text { National Institute of } \\
\text { Hygiene }\end{array}$ & Warsaw, Poland \\
\hline $\begin{array}{l}\text { Karen Krogfelt } \\
\text { and Tine Dalby }\end{array}$ & kak@ssi.dk; tid@ssi.dk & Statens Serum Institut & Copenhagen, Denmark \\
\hline Norman Fry & norman.fry@hpa.org.uk & $\begin{array}{l}\text { Health Protection } \\
\text { Agency }\end{array}$ & London, UK \\
\hline Dorothy Xing & dxing@nibsc.ac.uk & $\begin{array}{l}\text { National Institute for } \\
\text { Biological Standards } \\
\text { and Control }\end{array}$ & Potters Bar, UK \\
\hline $\begin{array}{l}\text { Camille Locht } \\
\text { and David Hot }\end{array}$ & camille.locht@pasteur-lille.fr; david.hot@pasteur-lille.fr & Institut Pasteur de Lille & Lille, France \\
\hline Clara Ausiello & ausiello@iss.it & $\begin{array}{l}\text { Istituto Superiore di } \\
\text { Sanità }\end{array}$ & Rome, Italy \\
\hline $\begin{array}{r}\text { Per Sandven and } \\
\text { Jann Storsaeter }\end{array}$ & per.sandven@fhi.no; jann.storsaeter@fhi.no & $\begin{array}{l}\text { Norwegian Institute } \\
\text { of Public Health }\end{array}$ & Oslo, Norway \\
\hline
\end{tabular}

\section{References}

1. André P, Caro V, Njamkepo E, Wendelboe AM, Van Rie A, Guiso N (2008) Comparison of serological and real-time PCR assays to diagnose Bordetella pertussis infection in 2007. J Clin Microbiol 46(5):1672-1677

2. Guiso N (2007) Laboratory manual for the diagnosis of whooping cough caused by Bordetella pertussis/Bordetella parapertussis.
World Health Organization (WHO). Available online at: http:// www.who.int/vaccines-documents/DocsPDF04/www788.pdf

3. Meade BD, Deforest A, Edwards KM, Romani TA, Lynn F, O'Brien CH, Swartz CB, Reed GF, Deloria MA (1995) Description and evaluation of serologic assays used in a multicenter trial of acellular pertussis vaccines. Pediatrics 96(3 Pt 2):570-575; Erratum in Pediatrics 1995 Dec;96(6):following 1199

4. Simondon F, Iteman I, Preziosi MP, Yam A, Guiso N (1998) Evaluation of an immunoglobulin $\mathrm{G}$ enzyme-linked immunosorbent 
assay for pertussis toxin and filamentous hemagglutinin in diagnosis of pertussis in Senegal. Clin Diagn Lab Immunol 5(2):130-134

5. Tondella ML, Carlone GM, Messonnier N, Quinn CP, Meade BD, Burns DL, Cherry JD, Guiso N, Hewlett EL, Edwards KM, Xing D, Giammanco A, Wirsing von König $\mathrm{CH}$, Han L, Hueston L, Robbins JB, Powell M, Mink CM, Poolman JT, Hildreth SW, Lynn F, Morris A (2009) International Bordetella pertussis assay standardization and harmonization meeting report. Centers for Disease Control and Prevention, Atlanta, Georgia, United States, 19-20 July 2007. Vaccine 27(6):803-814

6. Riffelmann M, Thiel K, Schmetz J, Wirsing von Koenig CH (2010) Performace of commercial enzyme-linked immunosorbent assays for the detection of antibodies to Bordetella pertussis. J Clin Microbiol, Oct. 13

7. Xing D, Wirsing von König CH, Newland P, Riffelmann M, Meade BD, Corbel M, Gaines-Das R (2009) Characterization of reference materials for human antiserum to pertussis antigens by an international collaborative study. Clin Vaccine Immunol 16(3):303-311

8. Dalby T, Sorensen C, Pedersen JW, Krogfelt KA (2010) Pertussis serology: assessment of a quantitative IgG-anti-PT ELISA for replacement of the CHO cell assay. APMIS (in press)

9. Reder S, Riffelmann M, Becker C, Wirsing von König CH (2008) Measuring immunoglobulin $\mathrm{G}$ antibodies to tetanus toxin, diphtheria toxin, and pertussis toxin with single-antigen enzymelinked immunosorbent assays and a bead-based multiplex assay. Clin Vaccine Immunol 15(5):744-749

10. van Gageldonk PGM, van Schaijk FG, van der Klis FR, Berbers GAM (2008) Development and validation of a multiplex immunoassay for the simultaneous determination of serum antibodies to Bordetella pertussis, diphtheria and tetanus. J Immunol Methods 335(1-2):79-89

11. Blumberg DA, Pineda E, Cherry JD, Caruso A, Scott JV (1992) The agglutinin response to whole-cell and acellular pertussis vaccines is Bordetella pertussis-strain dependent. Am J Dis Child 146(10):1148-1150

12. Granström G, Wretlind B, Salenstedt C-R, Granström M (1988) Evaluation of serologic assays for diagnosis of whooping cough. J Clin Microbiol 26(9):1818-1823

13. Litt DJ, Samuel D, Duncan J, Harnden A, George RC, Harrison TG (2006) Detection of anti-pertussis toxin IgG in oral fluids for use in diagnosis and surveillance of Bordetella pertussis infection in children and young adults. J Med Microbiol 55(Pt 9):1223-1228

14. Pebody RG, Gay NJ, Giammanco A, Baron S, Schellekens J, Tischer A, Olander RM, Andrews NJ, Edmunds WJ, Lecoeur H,
Lévy-Bruhl D, Maple PA, de Melker H, Nardone A, Rota MC, Salmaso S, Conyn-van Spaendonck MA, Swidsinski S, Miller E (2005) The seroepidemiology of Bordetella pertussis infection in Western Europe. Epidemiol Infect 133(1):159-171

15. de Melker HE, Versteegh FGA, Conyn-van Spaendonck MAE, Elvers LH, Berbers GAM, van der Zee A, Schellekens JFP (2000) Specificity and sensitivity of high levels of immunoglobulin $G$ antibodies against pertussis toxin in a single serum sample for diagnosis of infection with Bordetella pertussis. J Clin Microbiol 38(2):800-806

16. Versteegh FG, Mertens PL, de Melker HE, Roord JJ, Schellekens JF, Teunis PF (2005) Age-specific long-term course of IgG antibodies to pertussis toxin after symptomatic infection with Bordetella pertussis. Epidemiol Infect 133(4):737-748

17. Baughman AL, Bisgard KM, Edwards KM, Guris D, Decker MD, Holland K, Meade BD, Lynn F (2004) Establishment of diagnostic cutoff points for levels of serum antibodies to pertussis toxin, filamentous hemagglutinin, and fimbriae in adolescents and adults in the United States. Clin Diagn Lab Immunol 11(6): $1045-1053$

18. Horby P, Macintyre CR, McIntyre PB, Gilbert GL, Staff M, Hanlon M, Heron LG, Cagney M, Bennett C (2005) A boarding school outbreak of pertussis in adolescents: value of laboratory diagnostic methods. Epidemiol Infect 133(2):229-236

19. Ward JI, Cherry JD, Chang SJ, Partridge S, Keitel W, Edwards K, Lee M, Treanor J, Greenberg DP, Barenkamp S, Bernstein DI, Edelman R; APERT Study Group (2006) Bordetella pertussis infections in vaccinated and unvaccinated adolescents and adults, as assessed in a national prospective randomized Acellular Pertussis Vaccine Trial (APERT). Clin Infect Dis 43(2):151-157, Epub 2006 Jun 5

20. Marchant CD, Loughlin AM, Lett SM, Todd CW, Wetterlow LH, Bicchieri R, Higham S, Etkind P, Silva E, Siber GR (1994) Pertussis in Massachusetts, 1981-1991: Incidence, serologic diagnosis, and vaccine effectiveness. J Infect Dis 169(6):1297-1305

21. Yih WK, Lett SM, des Vignes FN, Garrison KM, Sipe PL, Marchant CD (2000) The increasing incidence of pertussis in Massachusetts adolescents and adults, 1989-1998. J Infect Dis 182(5):1409-1416

22. Wirsing von König $\mathrm{CH}$, Gounis $\mathrm{D}$, Laukamp S, Bogaerts H, Schmitt HJ (1999) Evaluation of a single-sample serological technique for diagnosing pertussis in unvaccinated children. Eur $\mathbf{J}$ Clin Microbiol Infect Dis 18(5):341-345 